\title{
Photodegradation of ceftriaxone in aqueous solution by using UVC and $\mathrm{UVC} / \mathrm{H}_{2} \mathrm{O}_{2}$ oxidation processes
}

\author{
Hassan Khorsandi ${ }^{1}$. Maryam Teymori ${ }^{1}$. Ali Ahmad Aghapour ${ }^{1} \cdot$ Seyed Javad Jafari ${ }^{1}$. Shabnam Taghipour ${ }^{2}$. \\ Rogaieh Bargeshadi ${ }^{1}$
}

Received: 8 September 2018 / Accepted: 25 April 2019 / Published online: 3 May 2019

(c) The Author(s) 2019

\begin{abstract}
This study investigated the performance of $\mathrm{UVC} / \mathrm{H}_{2} \mathrm{O}_{2}$ and UVC processes for the degradation and mineralization of ceftriaxone as an antibiotic. The highest ceftriaxone degradation was obtained at a solution $\mathrm{pH}$ of 5 and $\mathrm{H}_{2} \mathrm{O}_{2}$ concentration of $10 \mathrm{mg} / \mathrm{L}$. The apparent rate constant of ceftriaxone degradation was found to be $0.0302,0.0165$, and $0.0065 \mathrm{~min}^{-1}$ in the $\mathrm{UVC} / \mathrm{H}_{2} \mathrm{O}_{2}$ process for the initial ceftriaxone concentrations of 5,10 , and $20 \mathrm{mg} / \mathrm{L}$, respectively. Degradation and mineralization efficiencies of ceftriaxone was obtained to be $100 \%$ and $58 \%$, respectively, in $\mathrm{UVC} / \mathrm{H}_{2} \mathrm{O}_{2}$ process at reaction time of $120 \mathrm{~min}$, whereas only $61 \%$ and $2.5 \%$ of ceftriaxone could be degraded and mineralized by UVC. The synergistic effect of $\mathrm{UVC} / \mathrm{H}_{2} \mathrm{O}_{2}$ was found to be $35 \%$. The presence of anionic species improved the photolysis efficiency which degraded ceftriaxone from 61 to $83 \%$, while, in the $\mathrm{UVC} / \mathrm{H}_{2} \mathrm{O}_{2}$ process, ability degradation declined from 100 to $70 \%$. The efficiency of $\mathrm{UVC} / \mathrm{H}_{2} \mathrm{O}_{2}$ and $\mathrm{UVC}$ process was not greatly affected in real tap water. Besides, the reduction patterns in the $\mathrm{UVC} / \mathrm{H}_{2} \mathrm{O}_{2}$ and UVC processes were better described by pseudo-first- and second-order kinetics model with a reaction rate constant of 0.0165 and $0.0012 \mathrm{~min}^{-1}$, respectively. The rate constant of ceftriaxone degradation in the $\mathrm{UVC} / \mathrm{H}_{2} \mathrm{O}_{2}$ process and at the presence of radical scavenger was found to be around 3.3 times lower than the one in its absence.
\end{abstract}

Keywords Advanced oxidation process $\cdot$ Ceftriaxone $\cdot$ Degradation $\cdot \mathrm{UVC} / \mathrm{H}_{2} \mathrm{O}_{2}$

\section{Introduction}

In recent years, there has been an increasing attention to the incidence of pharmaceuticals and related products in the aquatic environment. The prevalent use of pharmaceuticals and their insufficient removal in wastewater treatment plants have increased their entrance into natural waters due to their refractory reaction to conventional biological processes (Munoz et al. 2017; Palominos et al. 2009). Among pharmaceuticals, antibiotics play a significant role in polluting the environment due to their frequent use in both veterinary and human medicine (Elmolla and Chaudhuri 2010; Palominos et al. 2009). Antibiotics have been detected in groundwater,

Seyed Javad Jafari

sjavadj@gmail.com

1 Department of Environmental Health Engineering, School of Public Health, Urmia University of Medical Sciences, Urmia, Iran

2 Department of Civil Engineering, Sharif University of Technology, Tehran, Iran surface water, sediments, and drinking water (Kümmerer 2009). Adverse effects of antibiotics on various organisms such as aquatic organisms, bacterial community, plants, and soil organisms have been found even at very low exposure concentrations (Wen et al. 2011). For instance, the bacteria derived from sewage bioreactors have depicted resistance to several antibiotics (Gulkowska et al. 2008). Therefore, it is essential to treat the effluents containing antibiotics before their discharge into the environment (Wen et al. 2011).

Ceftriaxone is an antibiotic that is effective for the treatment of some bacterial infections. It is a third-generation cephalosporin that prevents bacterial cell wall mucopeptide synthesis (Ratti et al. 2015; Shokri et al. 2016). This antibiotic is confirmed by the federal drug administration (FDA) for intramuscular or intravenous (IV) submissions at the maximum doses of 2-4 g daily for up to 4-6 weeks (Ratti et al. 2015). The antibiotic chemical that is used as a pharmaceutical product reached an estimation of 100,000 to 200,000 tons per year worldwide (Kummerer 2003). Diwan et al. (2009) studied antibiotic concentrations in hospital effluents in India and reported that high concentration of 
ceftriaxone in two samples was 58.3 and $59.5 \mu \mathrm{g} / \mathrm{L}$ (Diwan et al. 2009). Opris et al. (2013) collected samples from a wastewater treatment plant in Romania in order to detect antibiotics. The ceftriaxone detected in the influent wastewater samples was $334 \mu \mathrm{g} / \mathrm{L}$, and no target antibiotics were identified in effluent wastewater samples (Opris et al. 2013). Zuccato et al. (2000) detected ceftriaxone in the $\mathrm{ng} / \mathrm{L}$ range in river or drinking water and river sediments (Zuccato et al. 2000).

In recent years, advanced oxidation processes (AOPs) which produce hydroxyl radicals have been successfully employed as efficient methods for treating organic micropollutants in waters (Lester et al. 2010; Maya-Treviño et al. 2014). In these processes, the produced HO- radicals degrade organic contaminants since they are highly reactive and nonselective electrophiles which rapidly react with many pollutants at kinetic constants within the range of $10^{8}-10^{10} \mathrm{M}^{-1} \mathrm{~s}^{-1}$ (Lester et al. 2010; Yao et al. 2013).

The hydroxyl radicals can be generated through the combined application of ultraviolet light and hydrogen peroxide $\left(\mathrm{UV} / \mathrm{H}_{2} \mathrm{O}_{2}\right)$, which is one of the most frequently used AOP techniques in water treatment (Vogna et al. 2004b). Compared to chlorination, UV process is advantageous in terms of minimizing the formation of disinfection by-products and has been employed in water disinfection (Pereira et al. 2007). When photolysis is combined with hydrogen peroxide, a strong oxidant, the efficiency of process increased (Pereira et al. 2007). In this process which involves the use of UV/ $\mathrm{H}_{2} \mathrm{O}_{2}$, hydroxyl radicals are generated by photolysis of $\mathrm{H}_{2} \mathrm{O}_{2}$ according to the following equation (Hirsch et al. 1999):

$\mathrm{H}_{2} \mathrm{O}_{2}+\mathrm{UV} \rightarrow 2 \mathrm{OH}$.

In $\mathrm{UV} / \mathrm{H}_{2} \mathrm{O}_{2}$ process, some organic chemicals absorb UV light directly, leading to the destruction of the contaminant, and $\mathrm{H}_{2} \mathrm{O}_{2}$ addition is necessary to degrade resistant organic species (Kim et al. 2009). UV process is not an appropriate method for removing pharmaceuticals in wastewater treatment system; therefore, addition of $\mathrm{H}_{2} \mathrm{O}_{2}$ to the UV process is implemented to elevate the degradation rate (Kim et al. 2009; Lester et al. 2010). Many studies have effectively used the $\mathrm{UV} / \mathrm{H}_{2} \mathrm{O}_{2}$ process to degrade various organic pollutants (Kim et al. 2009; Mohagheghian et al. 2015; Moussavi et al. 2018; Vogna et al. 2004a). For instance, in a study, the use of $\mathrm{UV}$ and $\mathrm{UV} / \mathrm{H}_{2} \mathrm{O}_{2}$ for degrading carbamazepine showed that they could degrade carbamazepine very effectively, while direct photolysis was not effective for reducing this drug concentration (Vogna et al. 2004a).

Despite the prevalent use of ceftriaxone and the probability of its presence in aqueous environments which lead to serious concerns, there has been a rare attention to the degradation of this antibiotic in the literature. Shokri et al. (2016) investigated the photocatalytic degradation of ceftriaxone using immobilized $\mathrm{TiO}_{2}$ and $\mathrm{ZnO}$ nanoparticles. In
Table 1 Properties of ceftriaxone

\begin{tabular}{ll}
\hline chemical formula & $\mathrm{C}_{18} \mathrm{H}_{18} \mathrm{~N}_{8} \mathrm{O}_{7} \mathrm{~S}_{3}$ \\
\hline Molecular weigh & $554.58 \mathrm{~g} \mathrm{~mol}^{-1}$ \\
Chemical structure &
\end{tabular}

their study, the $\mathrm{UV} / \mathrm{TiO}_{2}$ process resulted in higher removal efficiencies (96.7\% COD in $480 \mathrm{~min}$ ) than that of the UV/ $\mathrm{ZnO}$ process (75\% COD in $480 \mathrm{~min}$ ).

Thus, the primary objective of this study was to assess the efficacy of UVC radiation and $\mathrm{UVC} / \mathrm{H}_{2} \mathrm{O}_{2}$ method in degrading and mineralizing ceftriaxone under different experimental conditions in aqueous solutions. In fact, the influences of the solution $\mathrm{pH}, \mathrm{H}_{2} \mathrm{O}_{2}$ concentration, ceftriaxone concentrations at different reaction times, kinetic of reactions, the presence of different anions, and water impurities on ceftriaxone degradation were investigated.

\section{Materials and methods}

\section{Reagents}

Ceftriaxone was purchased from Exir Pharmaceutical Co. (Tehran, Iran) and used in the experiments. The properties of ceftriaxone are given in Table 1 (Nirav 2012). The chemicals used in this study $\left(\mathrm{H}_{2} \mathrm{O}_{2}, \mathrm{H}_{2} \mathrm{SO}_{4}\right.$, and $\left.\mathrm{NaOH}\right)$ were of analytical grade and were obtained from the Merck.

\section{Experimental setup and procedure}

The experimental setup was a cylindrical glass reactor with an inner diameter of $40 \mathrm{~mm}$ and a height of $200 \mathrm{~mm}$ into which a quartz sleeve of $350 \mathrm{~mm}$ diameter was longitudinally inserted at the axial center. The photoreactor had a working volume of $100 \mathrm{~mL}$. A 9-W low-pressure mercury UV lamp (Philips, Holland) emitting a maximum wavelength of $254 \mathrm{~nm}$ and a light intensity of $2.2 \mathrm{~mW} / \mathrm{cm}^{2}$ was used as the radiation source. The reactor walls were wrapped by aluminum foil to prevent release of UV radiation to the ambient. The experiments were conducted in a bench-scale setup, as shown in Fig. 1. The influence of various important parameters including solution $\mathrm{pH}(5,7,9), \mathrm{H}_{2} \mathrm{O}_{2}$ concentration $(0,5,10,20,40,60,80$, and $100 \mathrm{mg} / \mathrm{L})$, ceftriaxone concentrations $(5,10,20 \mathrm{mg} / \mathrm{L})$ at different reaction time (5-120 min), kinetic of reactions, and the presence of different anions $\left(\mathrm{SO}_{4}{ }^{2-}, \mathrm{PO}_{4}{ }^{3-}, \mathrm{NO}_{3}{ }^{-}\right)$with concentration of $3 \mathrm{mM}$ and mixture of anions at tap water were examined to 


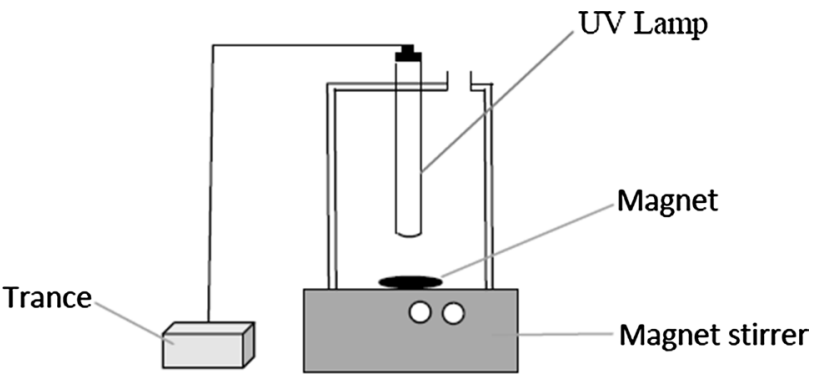

Fig. 1 The schematic of $\mathrm{UV} / \mathrm{H}_{2} \mathrm{O}_{2}$ experimental setup

evaluate the efficiency of the $\mathrm{UVC} / \mathrm{H}_{2} \mathrm{O}_{2}$ and UVC in degradation and mineralization of ceftriaxone in an aqueous solution. The samples were prepared dissolving ceftriaxone in twice-distilled water. In each run, the initial solution $\mathrm{pH}$ of $100 \mathrm{~mL}$ was adjusted to the specified value $(5,7$, 9) via adding dilute $0.1 \mathrm{M} \mathrm{HCl}$ or $0.1 \mathrm{M} \mathrm{NaOH}$ and was measured using pH meter (Philips PW 9422). Experimental studies were independently repeated twice, and the data are presented in terms of mean \pm standard deviation (SD). The space between UV source and solution was $2 \mathrm{~cm}$ in all experiments. During experiments, the solution in the reactor was constantly stirred at a rate of $100 \mathrm{rpm}$. In order to distinguish photolysis efficiency in degrading ceftriaxone, $100 \mathrm{~mL}$ of predetermined concentration of ceftriaxone solution was irradiated, and the removal efficiency was acquired after measuring ceftriaxone concentration at the end of radiation.

\section{Analytical methods}

After the appropriate irradiation time, samples were analyzed to determine the TOC and residual concentration of ceftriaxone and $\mathrm{H}_{2} \mathrm{O}_{2}$. Ceftriaxone concentration was measured using an Agilent 1260 infinity HPLC equipped with a ZORBAX Eclipse Plus C18 column ( $4.6 * 100 \mathrm{~mm}, 3.5 \mu \mathrm{m})$ with a diode array detector at $242 \mathrm{~nm}$. The mobile phase involved a phosphate buffer $(20 \mathrm{mM}) /$ acetonitrile $(90: 10)$ with an injection flow rate of $1 \mathrm{~mL} / \mathrm{min}$. The percentage of ceftriaxone degradation was calculated as:

Ceftriaxone degradation $=\left(1-\frac{C_{t}}{C_{0}}\right) \times 100$.

where $C_{0}$ and $C_{t}$ denote the ceftriaxone concentrations before and after process, respectively.

In order to specify the amount of mineralization, samples were taken out at certain time intervals and the organic content was determined by using a TOC analyzer (Shimadzu 5000). The TOC removal percentage was calculated based on the following equation:

TOC removal percentage $=\frac{\mathrm{TOC}_{0}-\mathrm{TOC}_{1}}{\mathrm{TOC}_{0}} \times 100$.

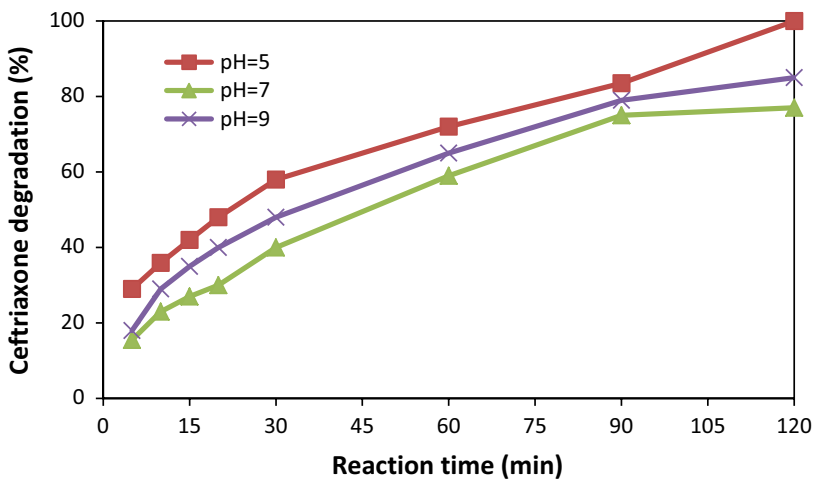

Fig. 2 Effect of $\mathrm{pH}$ on photocatalytic degradation (ceftriaxone $=10 \mathrm{mg} / \mathrm{L}, \mathrm{H}_{2} \mathrm{O}_{2}=10 \mathrm{mg} / \mathrm{L}$ )

where $\mathrm{TOC}_{0}$ and $\mathrm{TOC}_{1}(\mathrm{mg} / \mathrm{L})$ represent the initial and final TOC of the solution, respectively.

A specific amount of $\mathrm{H}_{2} \mathrm{O}_{2}(\mathrm{mg} / \mathrm{L})$ was added to reactor before the treatment, and no further hydrogen peroxide was added during the degradation. At the end of process, the residual concentration of hydrogen peroxide was determined through a spectrophotometer at $410 \mathrm{~nm}$ using titanium(IV) oxysulfate in accordance with the DIN 38402H15 method (Giannakis et al. 2017). To determine the apparent reaction rate constant $\left(k_{\text {app }}\right)$ values for the degradation of ceftriaxone, a pseudo-first-order kinetics model was used. The following equation shows the pseudo-first-order reaction kinetics:

$\mathrm{LnC}_{t}=\mathrm{Ln} C_{0}-K_{1} t$.

where $k_{1}$ is the apparent rate constant, and $C_{0}$ and $C_{t}$ are the ceftriaxone concentration at the beginning and after time $(t)$ of the reaction.

\section{Results and discussions}

\section{Effect of pH}

The effect of $\mathrm{pH}$ value was studied by adding incremental amounts of either diluted $\mathrm{H}_{2} \mathrm{SO}_{4}$ or $\mathrm{NaOH}$ to the ceftriaxone solution in the presence of $\mathrm{UVC} / \mathrm{H}_{2} \mathrm{O}_{2}$. Surprisingly, the degradation rate was observed to be lower in the alkaline media as compared to the one in the acidic media (Fig. 2). The photolytic ceftriaxone degradation appeared to be at its best level in acidic $\mathrm{pH}$ and lowest in neutral $\mathrm{pH}$. For example, after 120-min irradiation, the removal percentages of ceftriaxone were observed to be 100,77 , and $85 \%$ in $\mathrm{pH}$ levels of 5,7 , and 9 , respectively. The standard deviation was below $3 \%$ for all experiments.

The reduction in ceftriaxone degradation as a result of the increase in solution $\mathrm{pH}$ can be explained through the decomposition of $\mathrm{H}_{2} \mathrm{O}_{2}$ into $\mathrm{H}^{+}$, hydroperoxy anion 
$\left(\mathrm{HO}_{2}^{-}\right)$in alkaline $\mathrm{pH}$ [Eq. (5)], and reaction $\mathrm{HO}_{2}^{-}$to $\mathrm{H}_{2} \mathrm{O}_{2}$ [Eq. (6)], which cause the amount of $\mathrm{H}_{2} \mathrm{O}_{2}$ accessible for $\cdot \mathrm{OH}$ generation to reduce (Lin et al. 2016; Moussavi et al. 2018).

$$
\begin{aligned}
& \mathrm{H}_{2} \mathrm{O}_{2} \rightarrow \mathrm{H}^{+}+\mathrm{HO}_{2}^{-} \quad k=2.2 \times 10^{-12} \mathrm{M}^{-1} \mathrm{~s}^{-1} . \\
& \mathrm{H}_{2} \mathrm{O}_{2}+\mathrm{HO}_{2}^{-} \rightarrow \mathrm{H}_{2} \mathrm{O}+\mathrm{O}_{2}+\mathrm{OH}^{-} .
\end{aligned}
$$

Thus, higher solution $\mathrm{pH}$ led to an increase in $\mathrm{H}_{2} \mathrm{O}_{2}$ dissociation and therefore a decrease in the amount of hydroxyl free radical production. The total of these events reduces the process efficiency in alkaline media.

The mechanisms contributing to ceftriaxone degradation in $\mathrm{UVC} / \mathrm{H}_{2} \mathrm{O}_{2}$ process are (1) indirect reactions of ceftriaxone molecules to hydroxyl radicals and (2) absorption of UV radiation by ceftriaxone molecules and thus direct photolysis [Eqs. (7) and (8)].

ceftriaxoe $+\mathrm{OH}^{*} \rightarrow$ products

ceftriaxoe $+\mathrm{UV} \rightarrow$ products

In alkaline media, hydroperoxy anion $\left(\mathrm{HO}_{2}^{-}\right)$is formed, might react with the $\cdot \mathrm{OH}$ [Eq. (9)], and thus reduces the role of the main reaction [Eq. (7)] (Lin et al. 2016; Moussavi et al. 2018).

$$
\mathrm{OH}+\mathrm{HO}_{2}^{-} \rightarrow \mathrm{OH}_{2}^{\circ}+\mathrm{OH}^{-} \quad k=7.5 \times 10^{9} \mathrm{M}^{-1} \mathrm{~s}^{-1} .
$$

On the other hand, significant dissociation of $\mathrm{H}_{2} \mathrm{O}_{2}$ occurs at $\mathrm{pH}>11$. Thus, the role of $\mathrm{H}_{2} \mathrm{O}_{2}$ dissociation is not meaningful, and the reduction in ceftriaxone degradation at alkaline media can be due to the diminution of $\cdot \mathrm{OH}$ in the redox potential with the increase in $\mathrm{pH}$ level (Moussavi et al. 2018). AlHamedi et al. (2009) investigated the degradation of rhodamine $\mathrm{B}$ via $\mathrm{UV} / \mathrm{H}_{2} \mathrm{O}_{2}$ process and observed the maximum degradation of rhodamine $\mathrm{B}$ at acidic media $(\mathrm{pH}=3)$. Similarly, Shokri et al. (2016) reported that UV/ $\mathrm{TiO}_{2}$ process reached its maximum degradation $(92.8 \%)$ of ceftriaxone at $\mathrm{pH} 5.0$ after 120-min irradiation.

In the present study, in order to better understand the mechanism of ceftriaxone removal in the $\mathrm{UVC} / \mathrm{H}_{2} \mathrm{O}_{2}$ process, the removal efficiency of ceftriaxone in the presence of one radical scavenge (tert-butyl alcohol with a reaction rate constant of $6.0 \times 10^{8} \mathrm{M}^{-1} \mathrm{~s}^{-1}$ ) was examined. The results showed that (Fig. 2), within $120 \mathrm{~min}$, a complete degradation of ceftriaxone occurred in the $\mathrm{UVC} / \mathrm{H}_{2} \mathrm{O}_{2}$ process, while, in the presence of $0.5 \mathrm{~g}$ tert-butyl alcohol, the degradation efficiency of ceftriaxone decreased to $83.6 \%$ (the result is not shown). According to Fig. 3, under the same experimental conditions, the pseudo-first-order rate constant of ceftriaxone degradation in the $\mathrm{UVC} / \mathrm{H}_{2} \mathrm{O}_{2}$ process in presence of tert-butyl alcohol is around 3.3 times lower than that of the condition where it was absent. Accordingly, the presence of powerful hydroxyl radical scavenger reduces the reaction rate constant (Pignatello et al. 1999). This confirms that

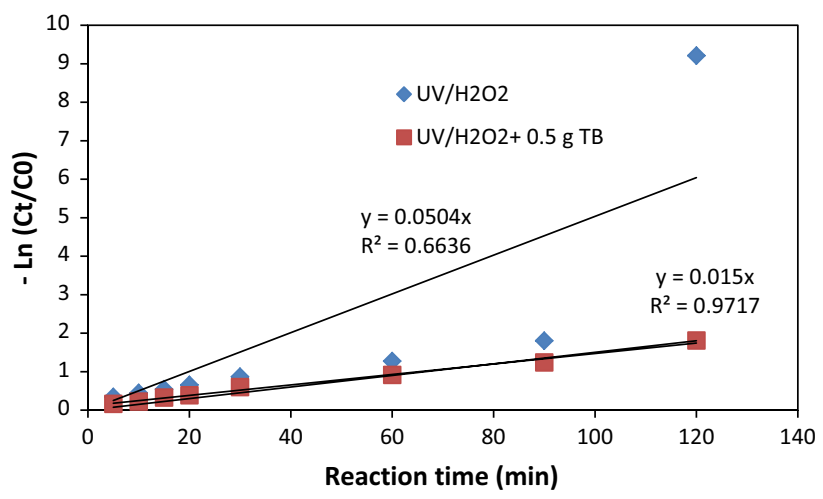

Fig. 3 Kinetic of the ceftriaxone degradation in the $\mathrm{UV} / \mathrm{H}_{2} \mathrm{O}_{2}$ process at the presence of tert-butyl alcohol as radical scavenger (ceftriaxone $=10 \mathrm{mg} / \mathrm{L}, \mathrm{H}_{2} \mathrm{O}_{2}=10 \mathrm{mg} / \mathrm{L}, \mathrm{pH}=5$, tert-butyl $=0.5 \mathrm{~g}$ )

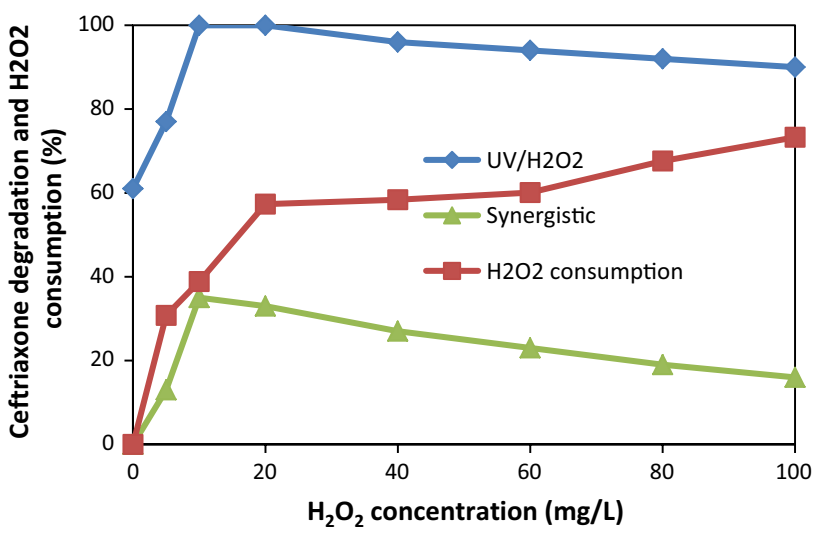

Fig. 4 Efficiency of $\mathrm{UVC} / \mathrm{H}_{2} \mathrm{O}_{2}, \mathrm{H}_{2} \mathrm{O}_{2}$ consumption, and synergistic effect of $\mathrm{UVC} / \mathrm{H}_{2} \mathrm{O}_{2}$ (ceftriaxone $=10 \mathrm{mg} / \mathrm{L}, \mathrm{pH}=5$, Time $=120 \mathrm{~min}$ )

hydroxyl radical [Eq. (7)] plays a major role in ceftriaxone degradation in the $\mathrm{UVC} / \mathrm{H}_{2} \mathrm{O}_{2}$ process.

\section{Effect of $\mathrm{H}_{2} \mathrm{O}_{2}$ concentration}

The effect of $\mathrm{H}_{2} \mathrm{O}_{2}$ concentration on $10 \mathrm{mg} / \mathrm{L}$ ceftriaxone degradation was investigated at $\mathrm{pH}=5$ and time reaction of $120 \mathrm{~min}$. Figure 4 demonstrates the efficiency of UVC, $\mathrm{UVC} / \mathrm{H}_{2} \mathrm{O}_{2}$, and $\mathrm{H}_{2} \mathrm{O}_{2}$ and synergistic effect of $\mathrm{UVC} / \mathrm{H}_{2} \mathrm{O}_{2}$ at various $\mathrm{H}_{2} \mathrm{O}_{2}$ concentrations of $0-100 \mathrm{mg} / \mathrm{L}$.

As Fig. 4 illustrates, in the absence of $\mathrm{H}_{2} \mathrm{O}_{2}$, the degradation efficiency is only $61 \%$ (photolysis process). This is due to the fact that hydroxyl radicals were produced only through photolysis (Eq. (10)) and photoionization of water molecules and in the absence of $\mathrm{H}_{2} \mathrm{O}_{2}$ (Eq. (11)).

$$
\begin{aligned}
& \mathrm{H}_{2} \mathrm{O}+\mathrm{UV} \rightarrow \mathrm{OH}^{-}+\mathrm{H}^{\circ} . \\
& \mathrm{H}_{2} \mathrm{O}+\mathrm{UV} \rightarrow \mathrm{OH}^{-}+\mathrm{H}^{+}+\mathrm{e}^{-} .
\end{aligned}
$$


Moreover, it can be concluded that the increase in $\mathrm{H}_{2} \mathrm{O}_{2}$ from 5 to $10 \mathrm{mg} / \mathrm{L}$ enhances the degradation efficiency from 77 to $100 \%$ and then remains constant up to $20 \mathrm{mg} / \mathrm{L} \mathrm{H}_{2} \mathrm{O}_{2}$ concentration. This phenomenon can be explained by the higher production of hydroxyl radicals due to the presence of $\mathrm{H}_{2} \mathrm{O}_{2}$ in the UVC reactor through reactions [Eqs. ( 1 and 12)] (Liao et al. 2016). Accordingly, $10 \mathrm{mg} / \mathrm{L} \mathrm{H}_{2} \mathrm{O}_{2}$ can be considered as an optimum addition loading for efficient degradation.

$\mathrm{H}_{2} \mathrm{O}_{2}+\mathrm{e}^{-} \rightarrow \mathrm{OH}^{-}+\mathrm{OH}^{-}$

Additional increases in $\mathrm{H}_{2} \mathrm{O}_{2}$ concentration above $20 \mathrm{mg} / \mathrm{L}$ decreases the degradation efficiency from 100 to $90 \%$. This is sensible considering the fact that, in the case of over plus $\mathrm{H}_{2} \mathrm{O}_{2}$, $\cdot \mathrm{OH}$ radicals efficiently react with $\mathrm{H}_{2} \mathrm{O}_{2}$ and produce hydroperoxyl radicals $\left(\mathrm{HO}_{2}^{-}\right)$[Eq. (13)] and hydroxyl free radicals generated at great dosage react with $\mathrm{HO}_{2}$ [Eq. (14)] or dimerize to $\mathrm{H}_{2} \mathrm{O}_{2}$ [Eq. (15)] (Daneshvar et al. 2007, 2008).

$\mathrm{OH}^{-}+\mathrm{H}_{2} \mathrm{O}_{2} \rightarrow \mathrm{HO}_{2}^{\prime}+\mathrm{H}_{2} \mathrm{O}$

$\mathrm{HO}_{2}+\mathrm{OH}^{\cdot} \rightarrow \mathrm{H}_{2} \mathrm{O}+\mathrm{O}_{2}$

$2 \mathrm{OH}^{\cdot} \rightarrow \mathrm{H}_{2} \mathrm{O}_{2}$

In this study to calculate the synergistic effect of $\mathrm{H}_{2} \mathrm{O}_{2}$ adding to the UVC process, the following equation is used:

synergistic effect $=\mathrm{R} \mathrm{UV} / \mathrm{H}_{2} \mathrm{O}_{2}-\left(\mathrm{R} \mathrm{UVC}+\mathrm{RH}_{2} \mathrm{O}_{2}\right)$

Removal efficiency of ceftriaxone at constant time (120 min) in UVC is $61 \%$, whereas, in $\mathrm{H}_{2} \mathrm{O}_{2}$ and UVC/ $\mathrm{H}_{2} \mathrm{O}_{2}$ of $10 \mathrm{mg} / \mathrm{L}$ dosage, it is 4 and $100 \%$, respectively. Thus, the synergistic effect of $\mathrm{UVC} / \mathrm{H}_{2} \mathrm{O}_{2}$ was found to be $35 \%$ [Eq. (16)]. This shows that the hydroxyl radicals generated from interactions between $\mathrm{H}_{2} \mathrm{O}_{2}$ and $\mathrm{UVC}$ in the $\mathrm{UVC} / \mathrm{H}_{2} \mathrm{O}_{2}$ process [Eqs. (1 and 12)] were the main species extremely contributed to ceftriaxone degradation (Moussavi et al. 2018). Peng et al. (2017) reported that the degradation of ibuprofen in $\mathrm{UVC} / \mathrm{H}_{2} \mathrm{O}_{2}$ process increased when the $\mathrm{H}_{2} \mathrm{O}_{2}$ concentration increased from 0.1 to $0.6 \mathrm{mM}$. In their study, the optimum concentration of $\mathrm{H}_{2} \mathrm{O}_{2}$ was obtained to be $0.54 \mathrm{mM}$.

\section{Kinetics of $\mathrm{UV} / \mathrm{H}_{2} \mathrm{O}_{2}$ and $\mathrm{UV}$ processes}

The influence of ceftriaxone concentration $(5-20 \mathrm{mg} / \mathrm{L})$ on its decay kinetic during $\mathrm{UV} / \mathrm{H}_{2} \mathrm{O}_{2}$ process at $\mathrm{pH}=5$ and $10 \mathrm{mg} / \mathrm{L} \mathrm{H}_{2} \mathrm{O}_{2}$ is presented in Fig. 5. It can be seen that the removal efficiencies of ceftriaxone decreased in accordance with the increasing in initial concentrations. For example, the increase in the initial concentration from 5 to $20 \mathrm{mg} / \mathrm{L}$ led to a decrease in the degradation efficiency from 81 to $43 \%$ at a 60 min irradiation time. This can be explained

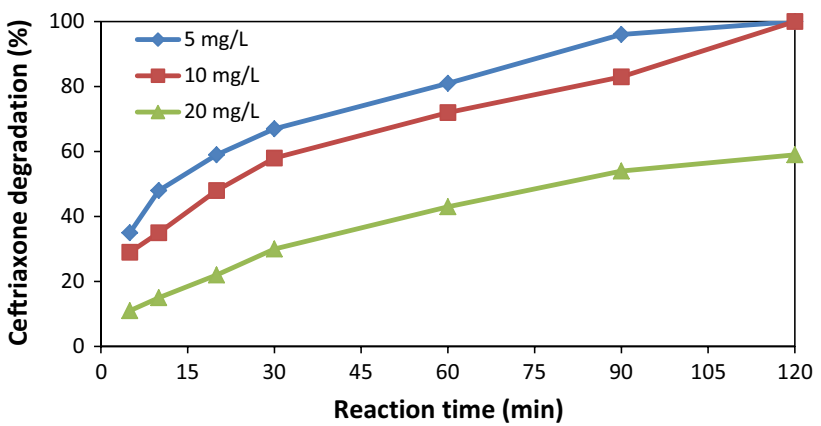

Fig. 5 Effect of initial ceftriaxone concentration on its degradation in the $\mathrm{UV} / \mathrm{H}_{2} \mathrm{O}_{2}\left(\mathrm{pH}=5, \mathrm{H}_{2} \mathrm{O}_{2}=10 \mathrm{mg} / \mathrm{L}\right)$

Table 2 Pseudo-first-order kinetic information of ceftriaxone degradation in $\mathrm{UV} / \mathrm{H}_{2} \mathrm{O}_{2}$ processes $\left(\mathrm{H}_{2} \mathrm{O}_{2}=10 \mathrm{mg} / \mathrm{L}, \mathrm{pH}=5\right)$

\begin{tabular}{lll}
\hline Ceftriaxone concentration $(\mathrm{mg} / \mathrm{L})$ & $K_{\text {app }}$ & $R^{2}$ \\
\hline 5 & 0.032 & 0.953 \\
10 & 0.0165 & 0.993 \\
20 & 0.0065 & 0.985 \\
\hline
\end{tabular}

considering that both the contaminant and $\mathrm{H}_{2} \mathrm{O}_{2}$ absorb $\mathrm{UV}$ radiation in the range emitted by the lamp (Aleboyeh et al. 2005). In addition, a greater amount of ceftriaxone molecules were in the reaction medium due to the increase in ceftriaxone concentration for a specified amount hydroxyl free radicals. Besides, an increased competition might be accomplished between ceftriaxone molecules and the degradation by-products with hydroxyl radicals oxidizing molecules (Sharma et al. 2015). These processes resulted in a reduction in ceftriaxone degradation efficiency due to an increase in initial concentration.

Table 2 demonstrates the calculated values of $K_{\text {app }}$ and liner correlation $\left(R^{2}\right)$ in case of pseudo-first-order kinetic for $\mathrm{UV} / \mathrm{H}_{2} \mathrm{O}_{2}$ process. According to table, in the $\mathrm{UVC} / \mathrm{H}_{2} \mathrm{O}_{2}$ process, the apparent rate constant of ceftriaxone degradation is $0.0302,0.0165$, and $0.0065 \mathrm{~min}^{-1}$ for the initial ceftriaxone concentrations of 5,10 , and $20 \mathrm{mg} / \mathrm{L}$, respectively. The decrease in $k_{\text {app }}$ due to the increase in ceftriaxone concentration can be attributed to the progressive acceleration of competitive reactions between $\mathrm{OH}$ radicals and the lately formed oxidant by-products of ceftriaxone during the process (El-Desoky et al. 2010). Li et al. (2018) used nanographite anode for electrochemical degradation of ceftriaxone sodium $(10 \mathrm{mg} / \mathrm{L})$ and found that the apparent rate constant is $0.01473 \mathrm{~min}^{-1}$. Hence, we can postulate that the treatment time required in $\mathrm{UVC} / \mathrm{H}_{2} \mathrm{O}_{2}$ process is 1.12 times lower than the one needed in electrochemical degradation of ceftriaxone using nano-graphite anode. In order to obtain the kinetic model in UV process, the experimental data were fitted with zero-, first-, and second-order equations. The

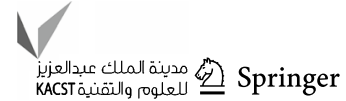



for the photolysis removal of ceftriaxone at different initial ceftriaxone concentrations $(\mathrm{pH}=5)$
Table 3 Kinetic parameters

\begin{tabular}{|c|c|c|c|c|c|c|}
\hline \multirow{2}{*}{$\begin{array}{l}\text { Ceftriaxone concentration } \\
(\mathrm{mg} / \mathrm{L})\end{array}$} & \multicolumn{2}{|c|}{ Zero order } & \multicolumn{2}{|c|}{ First order } & \multicolumn{2}{|c|}{ Second order } \\
\hline & $K$ & $R^{2}$ & $K$ & $R^{2}$ & $K$ & $R^{2}$ \\
\hline 5 & 0.02 & 0.919 & 0.007 & 0.967 & 0.0003 & 0.988 \\
\hline 10 & 0.039 & 0.926 & 0.006 & 0.969 & 0.0002 & 0.994 \\
\hline 20 & 0.072 & 0.955 & 0.005 & 0.98 & 0.001 & 0.995 \\
\hline
\end{tabular}
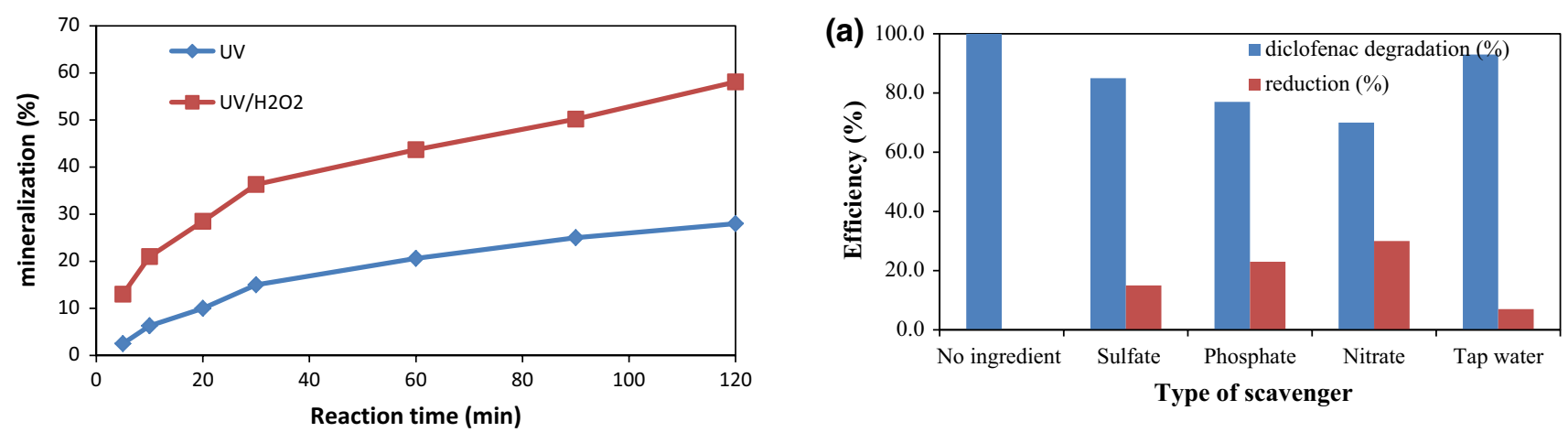

Fig. 6 Mineralization of ceftriaxone by $\mathrm{UVC} / \mathrm{H}_{2} \mathrm{O}_{2}$ and UVC (photolysis) process (ceftriaxone $=10 \mathrm{mg} / \mathrm{L}, \mathrm{H}_{2} \mathrm{O}_{2}=10 \mathrm{mg} / \mathrm{L}, \mathrm{pH}=5$ )

calculated values of reaction rate constant $(k)$ and the linear correlation coefficients $\left(R^{2}\right)$ for UV process are presented in Table 3 and indicate that the second-order reaction model exactly matched the experimental data with a determination coefficient $\left(R^{2}\right)$ greater than 0.98 for all concentrations.

\section{Mineralization of ceftriaxone by $\mathrm{UVC} / \mathrm{H}_{2} \mathrm{O}_{2}$ and $\mathrm{UVC}$}

The rate of ceftriaxone mineralization (based on TOC reduction) as a function of electrolysis time in the $\mathrm{UVC} / \mathrm{H}_{2} \mathrm{O}_{2}$ and $\mathrm{UVC}$ processes is depicted in Fig. 6. The $\mathrm{UVC} / \mathrm{H}_{2} \mathrm{O}_{2}$ process efficiency was obviously higher than that of UVC process. As shown in Fig. 6, after 120 min of treatment, 58\% of TOC was removed in $\mathrm{UVC} / \mathrm{H}_{2} \mathrm{O}_{2}$ process, while the $\mathrm{UVC}$ process mineralization increased from $2.5 \%$ at the reaction time of $5 \mathrm{~min}$ to $28 \%$ at the reaction time of $120 \mathrm{~min}$. As compared to its degradation, the lower rate of ceftriaxone mineralization can be relevant to the formation of organic by-products which are simpler than the ceftriaxone in terms of structure during the degradation process (Moussavi et al. 2018).

\section{Effect of anions on degradation of ceftriaxone in $\mathrm{UVC} / \mathrm{H}_{2} \mathrm{O}_{2}$ process}

The efficiency of $\mathrm{UVC} / \mathrm{H}_{2} \mathrm{O}_{2}$ and UV processes in the presence of several main water anions including phosphate, sulfate, and nitrate as well as in the tap water is depicted in Fig. 7a, b, respectively. The experiments carried out in the presence of several main water anions depicted a decrease in the removal efficiency of ceftriaxone in $\mathrm{UVC} / \mathrm{H}_{2} \mathrm{O}_{2}$ process. As shown in

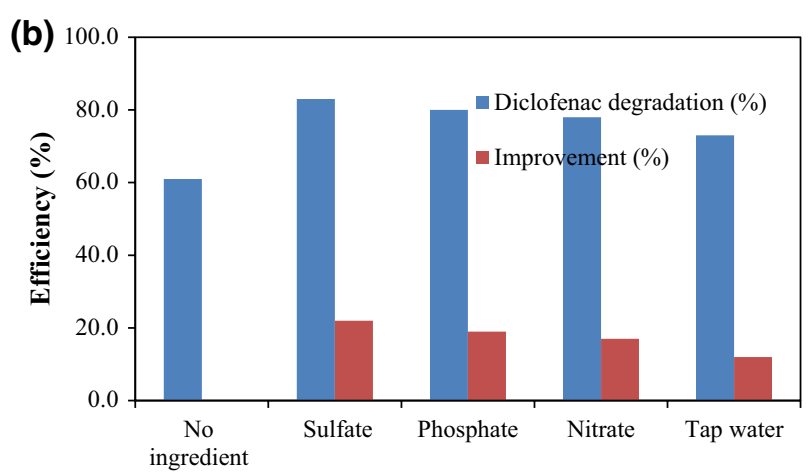

Type of scavenger

Fig. 7 Effect of anions on performance of the a $\mathrm{UV} / \mathrm{H}_{2} \mathrm{O}_{2}$ process and $\mathbf{b}$ photolysis process in ceftriaxone degradation (ceftriaxone $=10 \mathrm{mg} / \mathrm{L}, \mathrm{H}_{2} \mathrm{O}_{2}=10 \mathrm{mg} / \mathrm{L}, \mathrm{pH}=5$, Time $=120 \mathrm{~min}$ )

Fig. 7a, removal efficiency of ceftriaxone through $\mathrm{UVC} / \mathrm{H}_{2} \mathrm{O}_{2}$ in the absence of anions was $100 \%$, while, in the presence of sulfate, phosphate, and nitrate removal efficiency decreased to 85,77 , and $70 \%$, respectively. This is due to the fact that the anions react with $\cdot \mathrm{OH}$ radicals [Eqs. (17-19)], absorb the UV radiation and thus limit the amount of $\cdot \mathrm{OH}$ radical accessible for the ceftriaxone oxidation (Jafari et al. 2016; Moussavi et al. 2018; Sharma et al. 2016).

$\mathrm{SO}_{4}^{2-}+\mathrm{OH}^{-} \rightarrow \mathrm{SO}_{4}^{--}+\mathrm{OH}^{-} \quad k=1.5 \times 10^{6} \mathrm{M}^{-1} \mathrm{~s}^{-1}$

$\mathrm{NO}_{3}^{-}+\mathrm{OH} \rightarrow \mathrm{NO}_{3}^{\circ}+\mathrm{OH}^{-} \quad k=5 \times 10^{5} \mathrm{M}^{-1} \mathrm{~s}^{-1}$

$\mathrm{PO}_{4}^{2-}+\mathrm{OH}^{-} \rightarrow \mathrm{PO}_{4}^{--}+\mathrm{OH}^{-}$

The oxidation power of these anion radicals formed in these reactions (Eqs. 17-19) is much lower than that of 
hydroxyl radicals. On the other, these anion radicals may react with $\mathrm{H}_{2} \mathrm{O}_{2}$ and consume it (Moussavi et al. 2018). Therefore, the presence of anions caused a decrease in the removal efficiency of ceftriaxone in $\mathrm{UVC} / \mathrm{H}_{2} \mathrm{O}_{2}$ process. Moussavi et al. (2018) reported the greatest decrease in removal efficiency of BPA in the order of nitrate $>$ sulfate $>$ chloride $>$ bicarbonate. As Fig. 7a shows, the highest amount of reduction effect was related to nitrate (30\% reduction effect). This observation can be due to the absorption of UV by the nitrate which prevents the hydroxyl radicals generation reactions (Moussavi et al. 2014). The decrease in ceftriaxone degradation rate in the presence of sulfate and phosphate can be related to $\cdot \mathrm{OH}$ scavenging by these anions (Arany et al. 2014). In addition, Fig. 7a shows that the degradation efficiency in real tap water is $7 \%$ less than the one in distilled water solution. Therefore, the efficiency of $\mathrm{UV} / \mathrm{H}_{2} \mathrm{O}_{2}$ process in tap water did not greatly reduce. This can be due to the low concentration of these anions in the water (Moussavi et al. 2018).

As shown in Fig. 7b, removal efficiency of ceftriaxone through UV process in the absence of anions was $61 \%$, while, in the presence of sulfate, phosphate, and nitrate the removal efficiency enhanced to $83 \%, 80$, and $78 \%$, respectively. UV light converts of anions into anionic radicals whose oxidation power is higher than that of UV only irradiation (Sharma et al. 2016).

\section{Conclusion}

The efficiency of $\mathrm{UVC}$ and $\mathrm{UVC} / \mathrm{H}_{2} \mathrm{O}_{2}$ to ceftriaxone removal from aqueous solution was investigated. Optimum $\mathrm{H}_{2} \mathrm{O}_{2}$ dosage was equal to $10 \mathrm{mg} / \mathrm{L}$ which caused $35 \%$ synergistic effect on the photolysis process. The presence of $\mathrm{OH}$ in $\mathrm{UV} / \mathrm{H}_{2} \mathrm{O}_{2}$ process by reducing the reaction rate constant in the presence of tert-butanol as radical scavengers was verified. In the same conditions experiments, the pseudo-first-order rate constant of ceftriaxone degradation in the $\mathrm{UVC} / \mathrm{H}_{2} \mathrm{O}_{2}$ process at the presence of tert-butyl alcohol was around 3.3 times lower of its absence. Mineralization efficiency of ceftriaxone by $\mathrm{UVC} / \mathrm{H}_{2} \mathrm{O}_{2}$ and UVC after $120 \mathrm{~min}$ of treatment was equal to 28 and $58.1 \%$, respectively. The efficiency of $\mathrm{UV} / \mathrm{H}_{2} \mathrm{O}_{2}$ process in real tap water did not greatly reduce. The results of this study showed that the $\mathrm{UVC} / \mathrm{H}_{2} \mathrm{O}_{2}$ can be used as an appropriate way to remove pharmaceuticals from contaminated waters.

Acknowledgements We appreciate the Urmia University of Medical Science for providing financial and instrumental support to conduct this work.

\section{Compliance with ethical standards}

Conflict of interest The authors have replied that they have no conflicts of interest to declare.

Open Access This article is distributed under the terms of the Creative Commons Attribution 4.0 International License (http://creativeco mmons.org/licenses/by/4.0/), which permits unrestricted use, distribution, and reproduction in any medium, provided you give appropriate credit to the original author(s) and the source, provide a link to the Creative Commons license, and indicate if changes were made.

\section{References}

Aleboyeh A, Moussa Y, Aleboyeh H (2005) The effect of operational parameters on $\mathrm{UV} / \mathrm{H}_{2} \mathrm{O}_{2}$ decolourisation of Acid Blue 74. Dyes Pigm 66(2):129-134

Alhamedi FH, Rauf M, Ashraf SS (2009) Degradation studies of Rhodamine $\mathrm{B}$ in the presence of $\mathrm{UV} / \mathrm{H}_{2} \mathrm{O}_{2}$. Desalination 239(1-3):159-166

Arany E, Lang J, Somogyvari D, Lang O, Alapi T, Ilisz I, GajdaSchrantz K, Dombi A, Kohidai L, Hernadi K (2014) Vacuum ultraviolet photolysis of diclofenac and the effects of its treated aqueous solutions on the proliferation and migratory responses of Tetrahymena pyriformis. Sci Total Environ 468-469:996-1006

Daneshvar N, Behnajady M, Asghar YZ (2007) Photooxidative degradation of 4-nitrophenol (4-NP) in $\mathrm{UV} / \mathrm{H}_{2} \mathrm{O}_{2}$ process: influence of operational parameters and reaction mechanism. J Hazard Mater 139(2):275-279

Daneshvar N, Behnajady M, Mohammadi MKA, Dorraji MS (2008) $\mathrm{UV} / \mathrm{H}_{2} \mathrm{O}_{2}$ treatment of Rhodamine $\mathrm{B}$ in aqueous solution: influence of operational parameters and kinetic modeling. Desalination 230(1-3):16-26

Diwan V, Tamhankar AJ, Aggarwal M, Sen S, Khandal RK, Lundborg CS (2009) Detection of antibiotics in hospital effluents in India. Curr Sci 97:1752-1755

El-Desoky HS, Ghoneim MM, Zidan NM (2010) Decolorization and degradation of Ponceau $\mathrm{S}$ azo-dye in aqueous solutions by the electrochemical advanced Fenton oxidation. Desalination 264(1):143-150

Elmolla ES, Chaudhuri M (2010) Comparison of different advanced oxidation processes for treatment of antibiotic aqueous solution. Desalination 256(1):43-47

Giannakis S, Hendaoui I, Jovic M, Grandjean D, De Alencastro LF, Girault H, Pulgarin C (2017) Solar photo-Fenton and $\mathrm{UV} / \mathrm{H}_{2} \mathrm{O}_{2}$ processes against the antidepressant Venlafaxine in urban wastewaters and human urine. Intermediates formation and biodegradability assessment. Chem Eng J 308:492-504

Gulkowska A, Leung HW, So MK, Taniyasu S, Yamashita N, Yeung LW, Richardson BJ, Lei A, Giesy JP, Lam PK (2008) Removal of antibiotics from wastewater by sewage treatment facilities in Hong Kong and Shenzhen, China. Water Res 42(1):395-403

Hirsch R, Ternes T, Haberer K, Kratz K-L (1999) Occurrence of antibiotics in the aquatic environment. Sci Total Environ 225(1):109-118

Jafari SJ, Moussavi G, Hossaini H (2016) Degradation and mineralization of diazinon pesticide in $\mathrm{UVC}$ and $\mathrm{UVC} / \mathrm{TiO}_{2}$ process. Desalin Water Treat 57(8):3782-3790

Kim I, Yamashita N, Tanaka H (2009) Performance of UV and UV/ $\mathrm{H}_{2} \mathrm{O}_{2}$ processes for the removal of pharmaceuticals detected in secondary effluent of a sewage treatment plant in Japan. J Hazard Mater 166(2):1134-1140

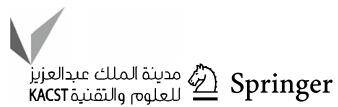


Kummerer K (2003) Significance of antibiotics in the environment. J Antimicrob Chemother 52(1):5-7

Kümmerer K (2009) Antibiotics in the aquatic environment-a reviewpart I. Chemosphere 75(4):417-434

Lester Y, Avisar D, Mamane H (2010) Photodegradation of the antibiotic sulphamethoxazole in water with $\mathrm{UV} / \mathrm{H}_{2} \mathrm{O}_{2}$ advanced oxidation process. Environ Technol 31(2):175-183

Li D, Guo X, Song H, Sun T, Wan J (2018) Preparation of $\mathrm{RuO}_{2}-\mathrm{TiO}_{2} /$ Nano-graphite composite anode for electrochemical degradation of ceftriaxone sodium. J Hazard Mater 351:250-259

Liao Q-N, Ji F, Li J-C, Zhan X, Hu Z-H (2016) Decomposition and mineralization of sulfaquinoxaline sodium during $\mathrm{UV} / \mathrm{H}_{2} \mathrm{O}_{2}$ oxidation processes. Chem Eng J 284:494-502

Lin C-C, Lin H-Y, Hsu L-J (2016) Degradation of ofloxacin using $\mathrm{UV} / \mathrm{H}_{2} \mathrm{O}_{2}$ process in a large photoreactor. Sep Purif Technol 168:57-61

Maya-Treviño M, Guzmán-Mar J, Hinojosa-Reyes L, Ramos-Delgado N, Maldonado MI, Hernández-Ramírez A (2014) Activity of the $\mathrm{ZnO}-\mathrm{Fe}_{2} \mathrm{O}_{3}$ catalyst on the degradation of Dicamba and 2, 4-D herbicides using simulated solar light. Ceram Int 40(6):8701-8708

Mohagheghian A, Karimi S-A, Yang J-K, Shirzad-Siboni M (2015) Photocatalytic degradation of a textile dye by illuminated tungsten oxide nanopowder. J Adv Oxid Technol 18(1):61-68

Moussavi G, Hossaini H, Jafari SJ, Farokhi M (2014) Comparing the efficacy of UVC, UVC/ZnO and VUV processes for oxidation of organophosphate pesticides in water. J Photochem Photobiol A 290:86-93

Moussavi G, Pourakbar M, Shekoohiyan S, Satari M (2018) The photochemical decomposition and detoxification of bisphenol A in the $\mathrm{VUV} / \mathrm{H}_{2} \mathrm{O}_{2}$ process: degradation, mineralization, and cytotoxicity assessment. Chem Eng J 331:755-764

Munoz M, Mora FJ, De Pedro ZM, Alvarez-Torrellas S, Casas JA, Rodriguez JJ (2017) Application of CWPO to the treatment of pharmaceutical emerging pollutants in different water matrices with a ferromagnetic catalyst. J Hazard Mater 331:45-54

Nirav BP (2012) Development and validation of stability indicating method for simultaneous estimation of ceftriaxone and sulbactam injection using RP-UPLC method. IOSR J Pharm 2:29-37

Opris O, Soran M-L, Coman V, Copaciu F, Ristoiu D (2013) Determination of some frequently used antibiotics in waste waters using solid phase extraction followed by high performance liquid chromatography with diode array and mass spectrometry detection. Cent Eur J Chem 11(8):1343-1351

Palominos RA, Mondaca MA, Giraldo A, Peñuela G, Pérez-Moya M, Mansilla HD (2009) Photocatalytic oxidation of the antibiotic tetracycline on $\mathrm{TiO}_{2}$ and $\mathrm{ZnO}$ suspensions. Catal Today 144(1):100-105
Peng M, Li H, Kang X, Du E, Li D (2017) Photo-degradation ibuprofen by $\mathrm{UV} / \mathrm{H}_{2} \mathrm{O}_{2}$ process: response surface analysis and degradation mechanism. Water Sci Technol 75(12):2935-2951

Pereira VJ, Weinberg HS, Linden KG, Singer PC (2007) UV degradation kinetics and modeling of pharmaceutical compounds in laboratory grade and surface water via direct and indirect photolysis at $254 \mathrm{~nm}$. Environ Sci Technol 41(5):1682-1688

Pignatello JJ, Liu D, Huston P (1999) Evidence for an additional oxidant in the photoassisted Fenton reaction. Environ Sci Technol 33(11):1832-1839

Ratti E, Berry JD, Greenblatt DJ, Loci L, Ellrodt AS, Shefner JM, Cudkowicz ME (2015) Preclinical rodent toxicity studies for long term use of ceftriaxone. Toxicol Rep 2:1396-1403

Sharma J, Mishra I, Kumar V (2015) Degradation and mineralization of Bisphenol A (BPA) in aqueous solution using advanced oxidation processes: $\mathrm{UV} / \mathrm{H}_{2} \mathrm{O}_{2}$ and $\mathrm{UV} / \mathrm{S}_{2} \mathrm{O}_{8}{ }^{2-}$ oxidation systems. J Environ Manag 156:266-275

Sharma AK, Tiwari RK, Gaur MS (2016) Nanophotocatalytic UV degradation system for organophosphorus pesticides in water samples and analysis by Kubista model. Arab J Chem 9:1755-1764

Shokri M, Isapour G, Shamsvand S, Kavousi B (2016) Photocatalytic degradation of ceftriaxone in aqueous solutions by immobilized $\mathrm{TiO}_{2}$ and $\mathrm{ZnO}$ nanoparticles: investigating operational parameters. J Mater Environ Sci 7(8):2843-2851

Vogna D, Marotta R, Andreozzi R, Napolitano A, D’ischia M (2004a) Kinetic and chemical assessment of the $\mathrm{UV} / \mathrm{H}_{2} \mathrm{O}_{2}$ treatment of antiepileptic drug carbamazepine. Chemosphere 54(4):497-505

Vogna D, Marotta R, Napolitano A, Andreozzi R, D'ischia M (2004b) Advanced oxidation of the pharmaceutical drug diclofenac with $\mathrm{UV} / \mathrm{H}_{2} \mathrm{O}_{2}$ and ozone. Water Res 38(2):414-422

Wen Q, Kong F, Zheng H, Yin J, Cao D, Ren Y, Wang G (2011) Simultaneous processes of electricity generation and ceftriaxone sodium degradation in an air-cathode single chamber microbial fuel cell. J Power Sources 196(5):2567-2572

Yao H, Sun P, Minakata D, Crittenden JC, Huang C-H (2013) Kinetics and modeling of degradation of ionophore antibiotics by UV and $\mathrm{UV} / \mathrm{H}_{2} \mathrm{O}_{2}$. Environ Sci Technol 47(9):4581-4589

Zuccato E, Calamari D, Natangelo M, Fanelli R (2000) Presence of therapeutic drugs in the environment. The Lancet 355(9217):1789-1790

Publisher's Note Springer Nature remains neutral with regard to jurisdictional claims in published maps and institutional affiliations. 